\title{
Determination of Antimicrobial Resistance Pattern in Methicillin-Resistant Staphylococcus saprophyticus and Staphylococcus epidermidis and Detection of Resistance Genes to Clindamycin and Erythromycin
}

\section{Hamed Tahmasebi ${ }^{1}$, Sanaz Dehbashi ${ }^{2}, \underline{\text { Mohammad Reza Arabestani }}{ }^{3}$}

1. Department of Microbiology, Zahedan University of Medical Sciences, Zahedan, Iran

2. Department of Microbiology, Hamadan University of Medical Sciences, Hamadan, Iran

3. Brucellosis Research Center, Hamadan University of Medical Sciences, Hamadan, Iran

Article Information

\section{Article history:}

Received: 2018/02/26

Accepted: 2018/08/05

Available online: $2018 / 10 / 11$

\section{Article Subject:}

Antibiotic Resistance

IJMM 2018; 12(3): 169-178

Corresponding author:

\section{Mohammad Reza Arabestani}

Brucellosis Research Center,

Hamadan University of Medical

Sciences, Hamadan, Iran

Tel: 09188662009

Email:

mohammad.arabestani@gmail.com

Use your device to scan

and read the article online

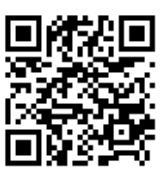

\section{Abstract}

Background and Aims: Clindamycin is one of the selective drugs for treatment of staphylococcal infections. Molecular methods can complete phenotypic methods to diagnosis induction resistance to clindamycin. The aim of this study was to identify the genes responsible for the resistance to clindamycin and erythromycin, and determine their antibiotic resistance pattern.

Materials and Methods: 100 isolates of Staphylococcus epidermidis and Staphylococcus saprophyticus were isolated from 466 different clinical specimens using biochemical tests. Using the disc diffusion method, Antibiogram susceptibility test was conducted to determinate lincosamides and tetracycline resistance pattern. Then ermA, ermB, ermC and $m s r A$ genes were identified and investigated by PCR method.

Results: Out of 100 strains of coagulase-negative staphylococci isolated from clinical specimens, 5 isolates were identified as $S$. saprophyticus $(5 \%)$ and 55 isolates of $S$. epidermidis (55\%), respectively. Out of the 5 isolated of S. saprophyticus, $2(40 \%)$ isolates were resistant to methicillin and one (20\%) isolate had D phenotype. In addition, 1 isolate had ermA gene and 1 isolate had ermB. Out of the 55 isolates of $S$. epidermidis, $25(45.45 \%)$ isolates were resistant to methicillin, of which nine (36\%) isolates had D phenotype. Also, $4(16 \%)$ isolates had ermA gene, $3(12 \%)$ isolates had ermB, 6 (24\%) isolates had $\mathrm{ermC}$ and $1(4 \%)$ isolate was carrying the msrA.

Conclusions: The phenotypic pattern of resistance to macrolide- lincosamides groups does not have a high degree of accuracy in detecting methicillin-resistant MLS $S_{\mathrm{B}}$ strains.

Keywords: Staphylococcus saprophyticus, Staphylococcus epidermidis, Methicillin resistance, Macrolides, Lincosamides

Copyright @ 2018 Iranian Journal of Medical Microbiology. All rights reserved.

How to cite this article:

Tahmasebi H, Dehbashi S, Arabestani M R. Determination of Antimicrobial Resistance Pattern in Methicillin-Resistant Staphylococcus saprophyticus and Staphylococcus epidermidis and Detection of Resistance Genes to Clindamycin and Erythromycin. Iran J Med Microbiol. 2018; 12 (3) :169-178 


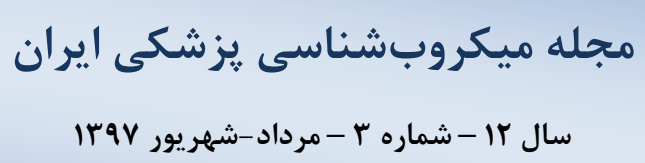

Journal homepage: www.ijmm.ir
مقاله

بثزوهشى

\title{
تعيين الكوى مقاومت آنتىبيو تيكى در جدايهاى استافيلوكوكوس سابروفيتيكوس و استافيلوكوكوس /ِيدرميليس مقاوم به متىسيلين و رديابى رنهاى مقاومت به كليندامايسين و اريترومايسين
}

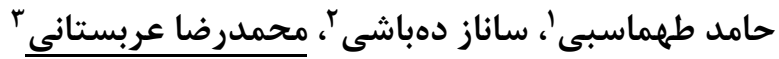

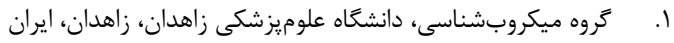

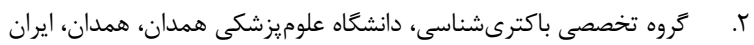

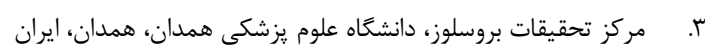

\begin{tabular}{|c|c|}
\hline جـكيله & اطلاعات مقاله \\
\hline & تاريخجهُ مقاله \\
\hline زمينه و هدف: يكى از داروهاى منتخب براى درمان برخى از عفونتهاى استافيلوكوكوسى، كليندامايسين است. روشهاى & 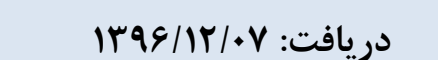 \\
\hline 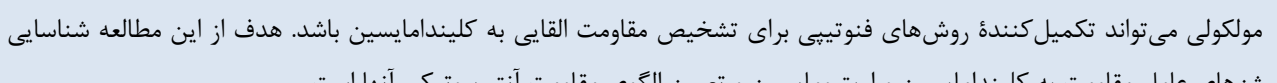 & 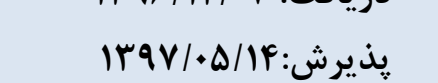 \\
\hline رنهاى عامل مقاومت به كليندامايسين و اريترومايسين و تعيين الكوى مقاومت انتىبيوتيكى انها است. & 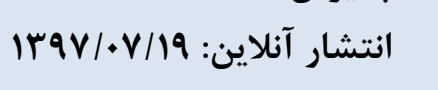 \\
\hline بيوشيميايى جداسازى شدند. با استفاده از روش ديسك ديفيوزن الكَى مقاومت آنتىبيوتيكى نسبت به لينكوزاميدها و تتراسايكلينها & 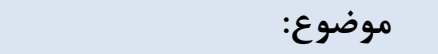 \\
\hline به دست آمد. سيس، رنهاى msrA , ermC , ermB ermA با استفاده از روش PCR شناسايى و بررسى شدند. & مقاومت پِادزيستى (آنتى بيوتيكى) \\
\hline يافتهها: از .ا جدائٔ /ستافيلوكوكوس كواكولاز منفى جداشده از نمونههاى بالينى مختلف، ه جدايه /ستافيلوكوكوس & IJMM1397;12(3): 169-178 \\
\hline 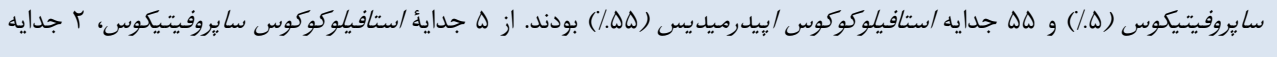 & نو نسندة مسئول: \\
\hline 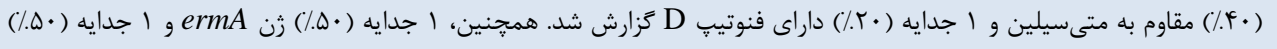 & \\
\hline 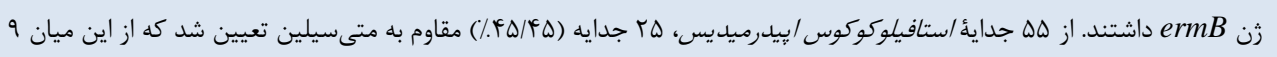 & محمدرز \\
\hline 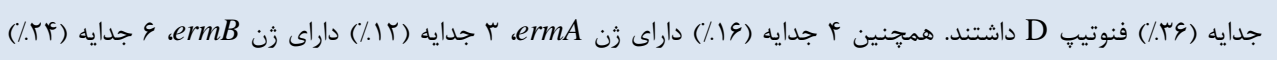 & مركز تحقيقات بروسلوز، دانشگاه علوم \\
\hline 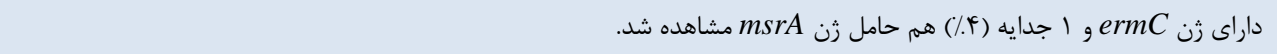 & \\
\hline نتيجه كيرى: الكَوى فنوتيبى مقاومت به كروههاى ماكروليدى ـ لينكوزاميدى، دقت بالايى براى تشخيص سويههاى MLSB & 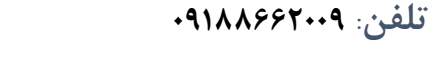 \\
\hline 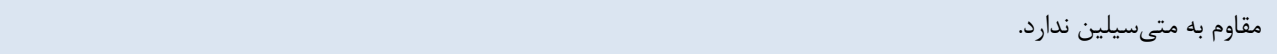 & 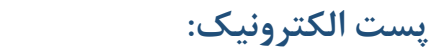 \\
\hline كلمات كليدى: /ستافيلوكوكوس سايروفيتيكوس، /ستافيلوكوكوس /بيدرميديس، مقاومت به متىسيلين، ماكروليد، لينكوزاميد & $\begin{array}{l}\text { mohammad.arabestani } \\
\text { @gmail.com }\end{array}$ \\
\hline 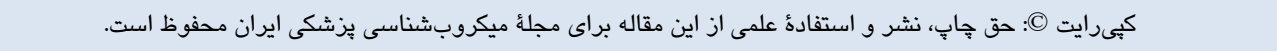 & \\
\hline
\end{tabular}

باكترى از طريق اتصال به 23SrRNA ريبوزومى اشاره كرد. MLS

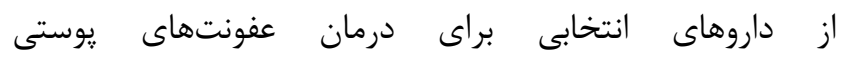
استافيلوكوكوسى مقاوم به متىسيلين هستند كه استفاده كسترده

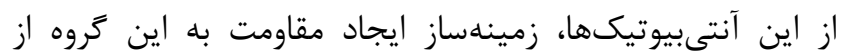

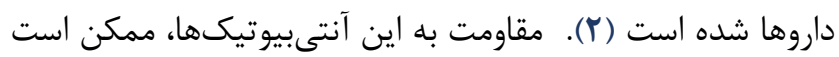

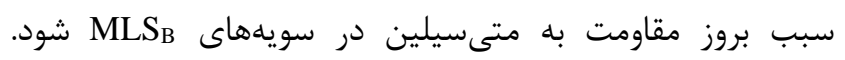

ماكروليد ـ لينكوزاميد ـ استرويتوگرامين (MLSB از آنتىبيوتيكها هستند كه براى درمان عفونتهاى ناشى از

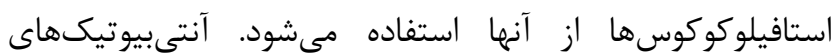
تفاوتهاى ساختارى مختلفى با يكديكر دارند؛ اما عملكرد

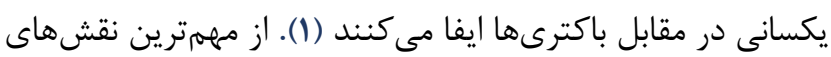

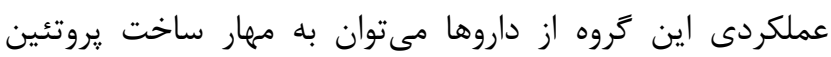


و به اين ترتيب مىتواند سبب القاى مقاومت در كليندامايسين

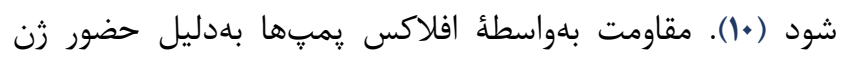
است كه باعث مقاومت ساختارى به اريترومايسين و و

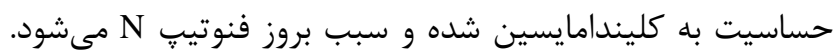
اسـتافيلوكوكوسهـاى داراى زن كد مى كنند كه موجب ايجاد مقاومت ساختارى نسبت به اريترومايسين و حساسيت نسبت بـهـ كليندامايسسين مىشود. بــهـ ايزولههاى داراى زن msrA، اصـطلاحاً ايزولـههــاى

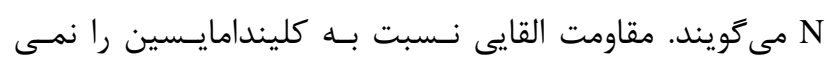
تـوان بـا اسـتفاده از روشهاى آنتىبيوگرام معمول تشخيص داد داد (1). اين احتمـال وجـود دارد كه ايزولههاى iMLSB حين درمان، دجار موتاسيون شده و تبـديل بـه cMLSB شـوند و بنـابراين

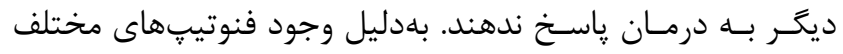

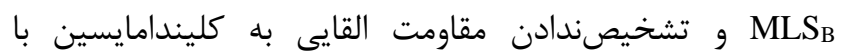
روشهاى آنتىبيوگرام معمول، بسيارى از يزشكان با ديدن مقاومت

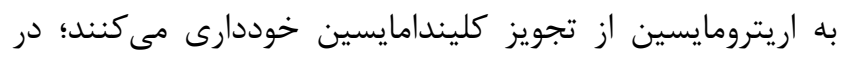

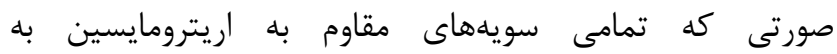
كليندامايسين مقاوم نيستند (Iا،ب). اين امر سبب شده است كه

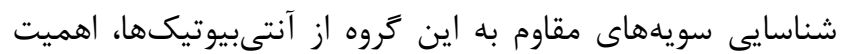

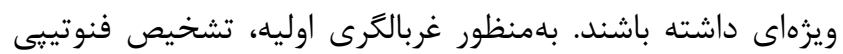

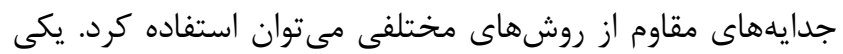

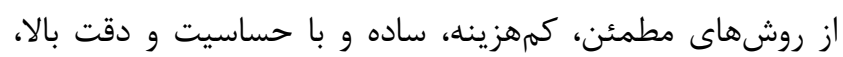
روش D-Test است. در كنار اين روش، مى متوان از PCR بهعنوان يك روش دقيقتر استفاده كرد. هدف از اين مطالعه شناسايى زنهاى عامل مقاومت به كليندامايسين - اريترومايسين و تعيين الكوى مقاومت آنتىبيوتيكى در جدايههاى بالينى /ستافيلوكوكوس

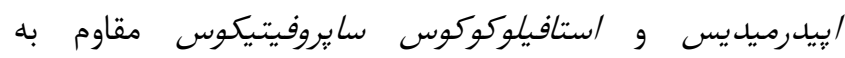
متىسيلين است.

\section{مواد و روش ها}

\section{جمع آورى و كشت نمونهها}

در مرحلة نخست اين مطالعه كه از نوع توصيفى - مقطعى

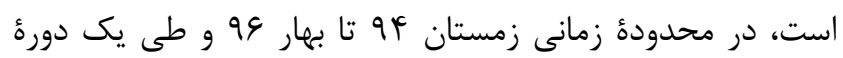
rاماهه، نخاعى، سواب بينى، زخم و ساير) از مراكز منتخب درمانى دانشگاه

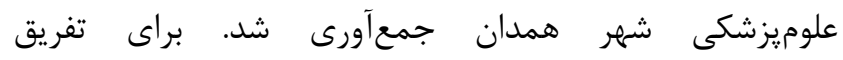
استافيلوكوكوسها از استريتوكوكوسها از آزمون كاتالاز استفاده شد. براى تشخيص استافيلوكوكوسها از ميكروكوكوسها نيز از
مقاومت به متىسيلين در استافيلوكوكوسها بهدليل توليد يروتئينى به نام Penicillin-Binding Protein 2 (PBP2) است كهيت ميل تركيبى كمى با بتالاكتامها دارد و سبب مقاومت به بتالاكتام

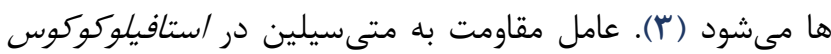
سابروفيتيكوس و /ستافيلوكوكوس /بيدرميديس، زن مecA است كه باعث بيانشدن :بروتئين PBP2a در باكترى شده و مانع اتصال

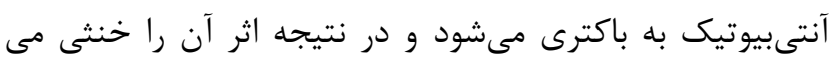

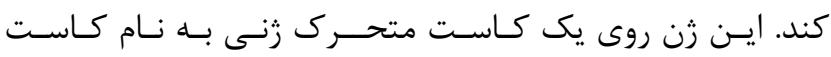

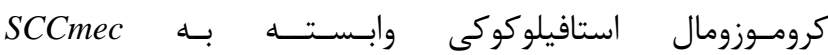
قرار كرفته كه (Staphylococcal Cassette Chromosome mec)

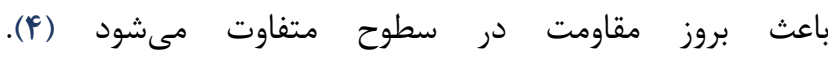

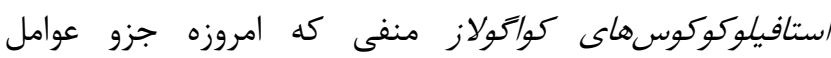
ايجادكننده عفونتهاى بيمارستانى دستهبندى مىشوند، با كسب

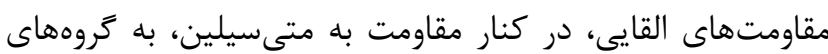

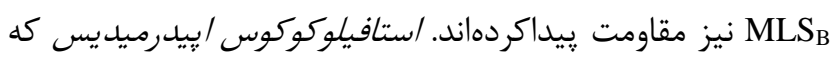

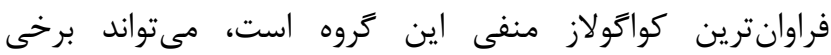

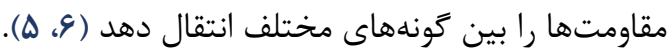
مقاومت به آنتىبيوتيكهاى گروه MLS متفاوت به وجود مىآيد كه عبارتاند از: تغيير سايت هدف بيون

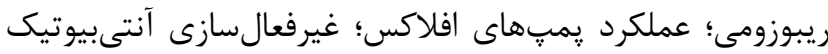

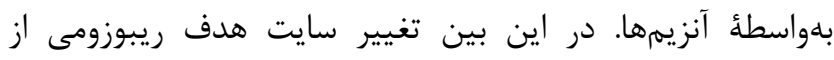
شايعترين مكانيسهماى مقاومتى است كه از طريق زنهاى (erm) erythromycin ribosome methylase زنهاى موجود در استافيلوكوكوسها، بر يلاسميدها يا ترانسيوزون هـا حمل مىشوند كه با توليد آنزيمهاى متيلاز سبب متيلاسيون زيرواحد 23SrRNA ريبوزومى شده و درنهايت مانع اتصال آنتى بيوتيك به جايكاه ريبوزومى خود مىشود (1). اين رويه باعث بروز مقاومت به ماكروليدها، لينكوزاميدها و استريتوگرامين مىشود. اين نوع مقاومتها كه به دو صورت مقاومت دائمى مرون (inducible $\mathrm{MLS}_{\mathrm{B}}$ ) و مقاومت القايى (constitutive $\mathrm{MLS}_{\mathrm{B}}$ ) هستند، از طريق مجموعهاى از زنهاى ermB شامل ermA، ermF و ermC، دائمى cMLSB، متيلازهاى mRNA بدون نياز به القاكننده توليد مىشوند كه در اين حالت، سويههاى مقاومشده به تمامى

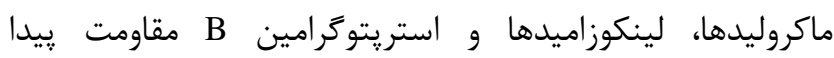
مى كنند. در مقاومت القايى iMLS ، متيلازهاى mRNA فقط در

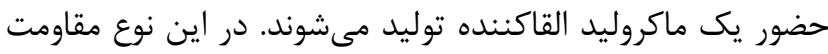
اريترومايسين بهعنوان يك عامل القاكننده توليد متيلاز عمل كرده 
استافيلوكوكوس اورئوس ATCC33591 بهعنوان سوية استاندارد

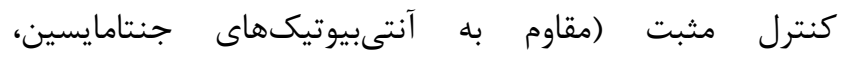

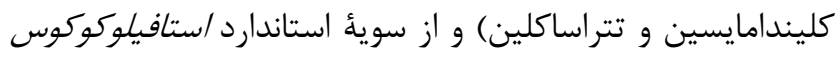

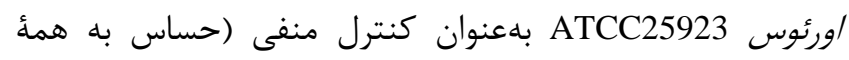

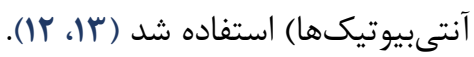

\section{تعيين سويههاى استافيلوكوكوس /بيدرميديس و و}

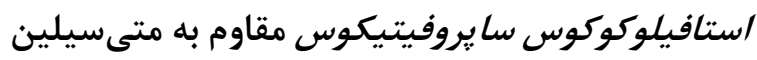

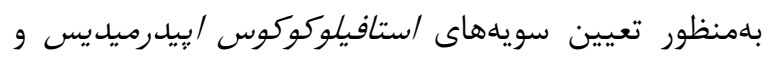
استافيلوكوكوس سابروفيتيكوس مقاوم به متىسيلين، روش تعيين

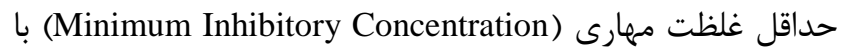

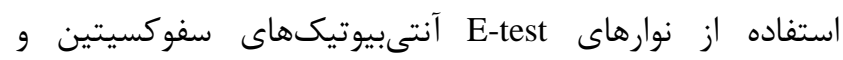

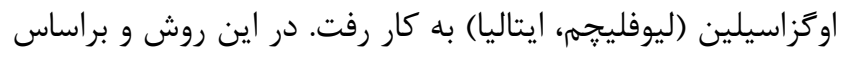

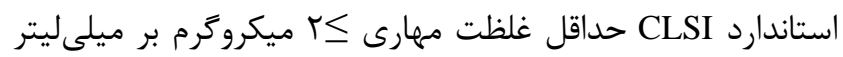

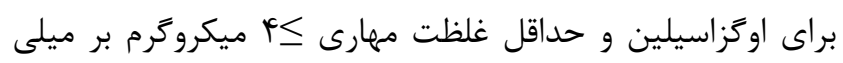

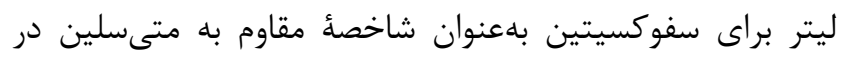
نظر كرفته شد (r).

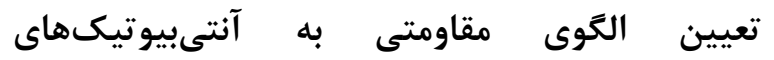
آمينوكليكوزيدى در استافيلوكوكوس اورئوس نمونههاى /ستافيلوكوكوس /ورئوس با استفاده از ديسكونهاى

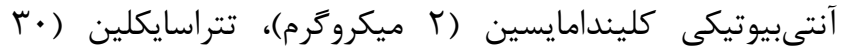

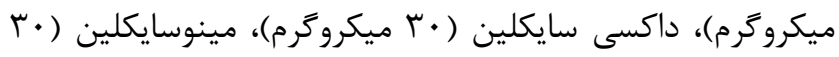

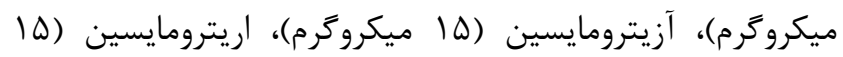

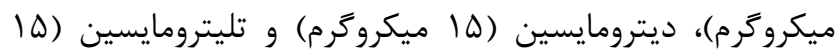
ميكرو مرم) (انخلستان) (MAST) به روش ديسك ديفيوزن تعيين

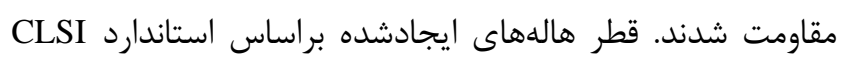

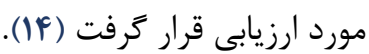

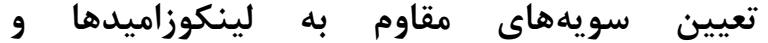
تتراسايكلينها با آزمون القا

بدين منظور، از ديسكهاى كليندامايسين (r ميكروگرم)

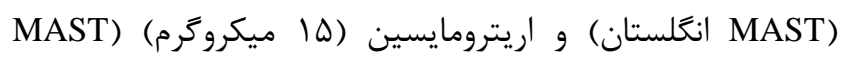

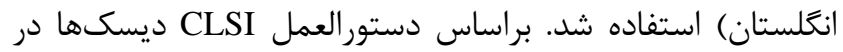

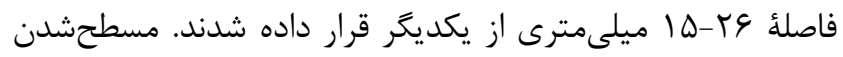

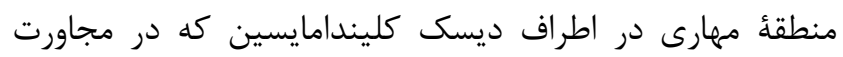

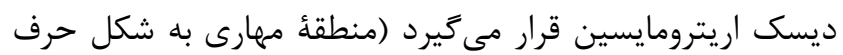

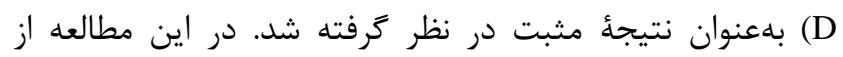

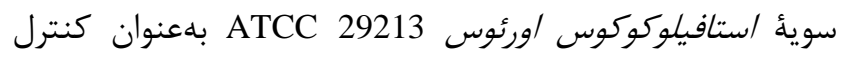

آزمايش اكسيداسيون و احيا استفاده شد. براى تفكيك

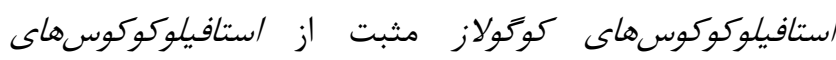

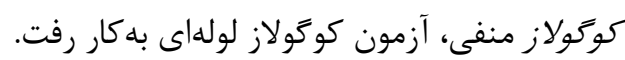

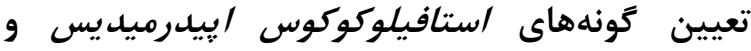
استافيلوكوكوس سابروفيتيكوس

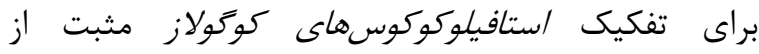

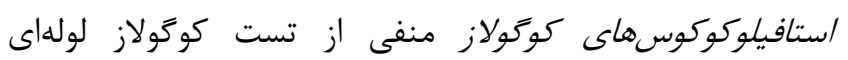

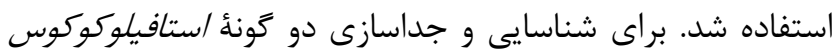
سابروفيتكوس از /ستافيلوكوكوس / بيدرميديس علاوه بر استفاده از ازئ

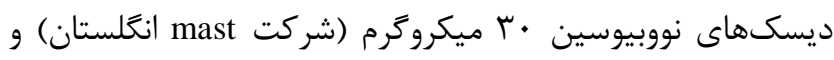

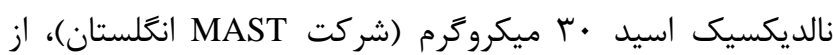
تستهاى PYR (شركت Key Diagnostics Pty استراليا)، آزمون دكربوكسيلاسيون اورنيتين، توليد اسيد از قندهاى مالتوز، ترهالوز،

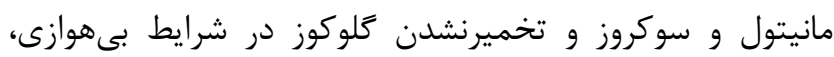
كمك كرفته شد. در روش ديسك انتشارى ابتدا يك سوسيانسيون

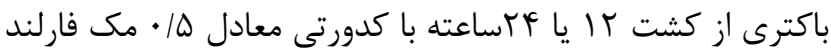

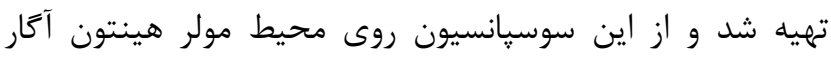
(شركت Merck آلمان) با ضخامت ه ميلىمتر كشت داده شد.

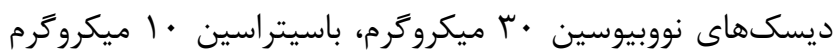

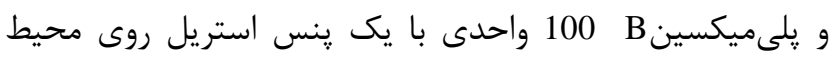

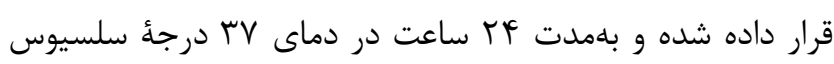
Clinical \& Laboratory انكوبه شدند. طبق آخرين نسخه Standards Institute(CLSI)

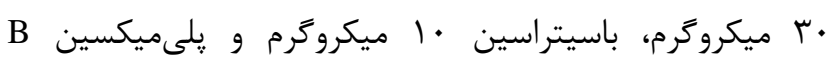

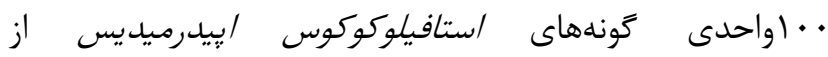

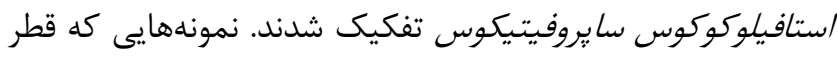

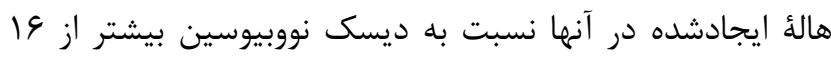

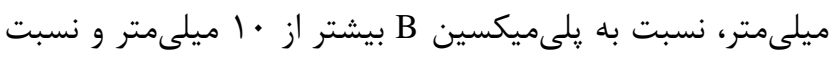
به باسيتراسين بيشتر از 9 ميلىمتر مشاهده مىشد، بلعندوان

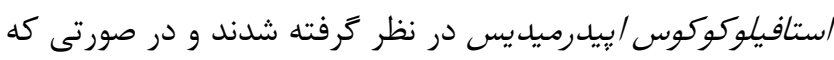

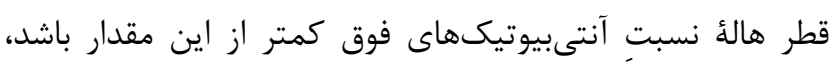
نمونه بهعنوان /ستافيلوكوكوس سايروفيتيكوس در نظر كرفته شد.

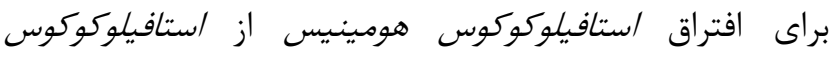

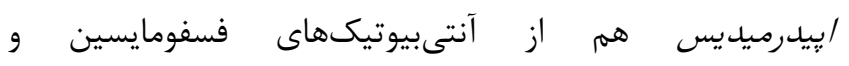

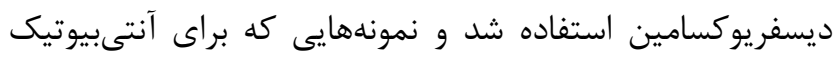

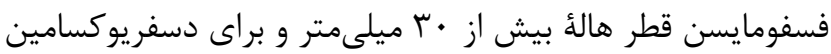

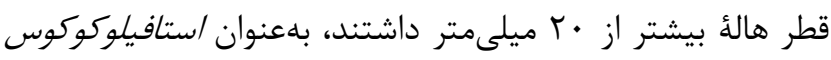
إِيدرميديس در نظر كرفته شدند. در روند شناسايى از سوئ 


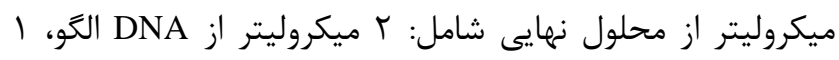

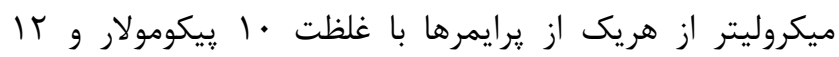

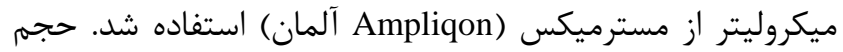

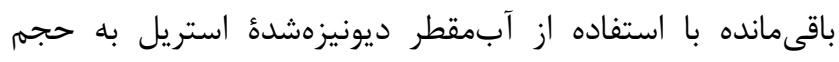

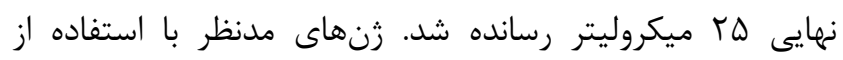

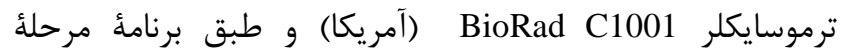

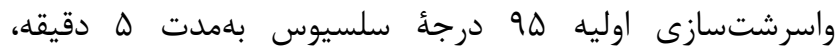

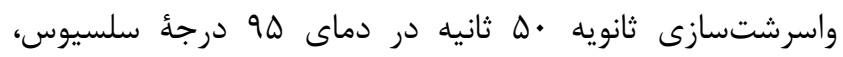

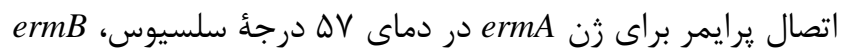

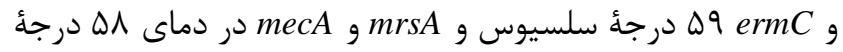

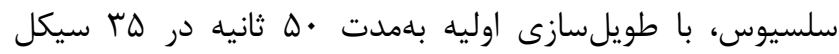

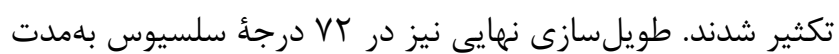

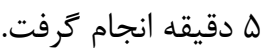

مثبت و از سويأ /ستافيلوكوكوس اورئوس ATCC25923 بهنتوان كنترل منفى استفاده شد (ه).

\section{استخراج زنومى با استفاده از كيت استخراج} براى انجام استخراج DNA رنوميك از كيت (سينا كلون، ايران) استفاده شد. مراحل استخراج طبق دستورالعمل مندرج دراج درد

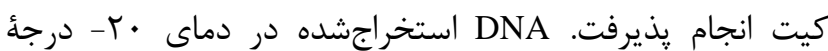
سلسيوس ذخيرهسازى شد (1) أنجام برفت

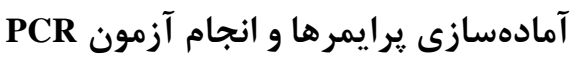

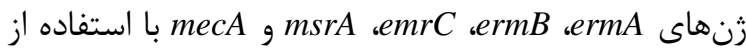
روش PCR در جدايههاى داراى مقاومت به متىسيلين بررسى شد. براى آمادهازى شرايط اوليه، ابتدا براساس حجم تعيينشده

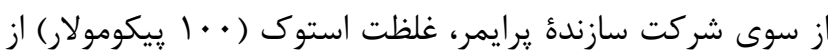

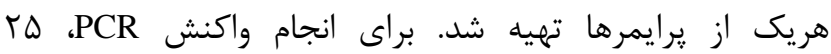

\begin{tabular}{|c|c|c|c|}
\hline رفرنس & اندازه (bp) & طول توالى & زنهاى مدنظر \\
\hline (IV) & FrI & $\begin{array}{l}\text { F: GTTCAAGAACAATCAATACAGAG } \\
\text { R: GGATCAGGAAAAGGACATTTTAC }\end{array}$ & ermA \\
\hline (IV) & $r \Delta q$ & $\begin{array}{c}\text { F:CCGTTTACGAAATTGGAACAGGTAAAGGG } \\
\text { C R: GAATCGAGACTTGAGTGTGC }\end{array}$ & ermB \\
\hline (IV) & $\Delta V Y$ & $\begin{array}{l}\text { F: GCTAATATTGTTTAAATCGTCAATTCC } \\
\text { R: GGATCAGGAAAAGGACATTTTAC }\end{array}$ & erm B \\
\hline (^) & 194 & $\begin{array}{l}\text { F: TCCAATCATTGCACAAAATC } \\
\text { R: AATTCCCTCTATTTGGTGGT }\end{array}$ & $m s r A$ \\
\hline (^) & זו. & $\begin{array}{l}\text { F: GTAGAAATGACTGAACGTCCGATGA } \\
\text { R: CCAATTCCACATTGTTTCGTCTAA }\end{array}$ & mecA \\
\hline
\end{tabular}

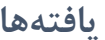

\section{نتايج حاصل از جداسازى جدايهها: از مجموع ..1} جدايه استافيلوكوكوس كواتولاز منفى جداشده از نمونهاى

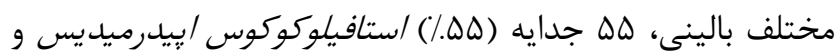
ه جدايه (ه./) /ستافيلوكوكوس سايروفيتيكوس بودند. از هله جدائ

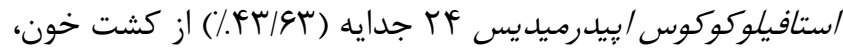

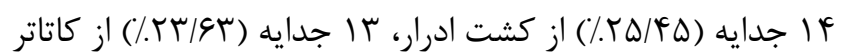

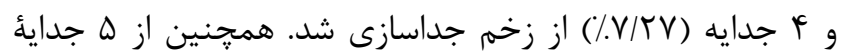

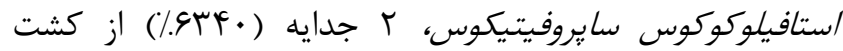

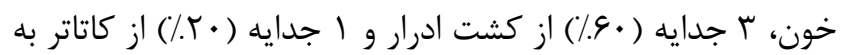
دست آمد. ساير نمونههاى بالينى فاقد باكترىهاى مطالعهشده

نتايج تعيين حداقل غلظت مهارى سفوكسيتين و اكزاسيلين: در روش تعيين حداقل غلظت مهارى با استفاده از
الكتروفورز روى زل اكارز ه/ا درصد

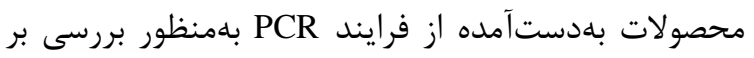

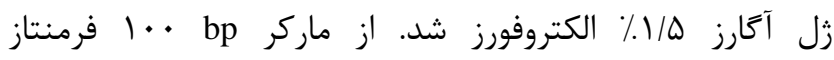
براى شناسايى باندهاى مدنظر استفاده شد. در اين بررسى از سوية استاندارد /ستافيلوكوكوس اورئوس ATCC33591 و ATCC43300 بردعنوان كنترل مثبت و از سويئ استافيلوكوكوس /ورئوس ATCC25923 بهعنوان كنترل منفى

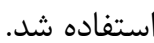

\section{تجزيلهو تحليل دادهها}

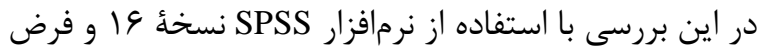

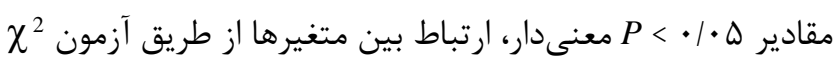

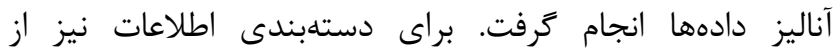
روشهاى آمارى توصيفى (تعيين فراوانى، درصد و ميانگَين)

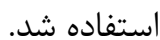


نتايج مقاومت براساس آزمونهاى فنوتييى: از

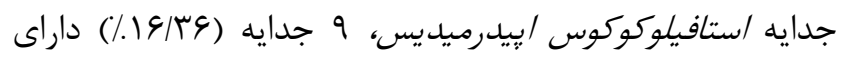

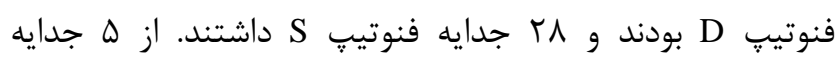

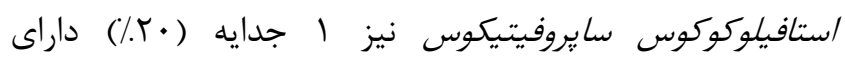

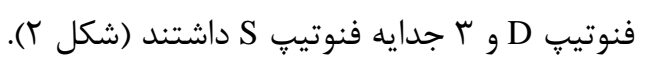

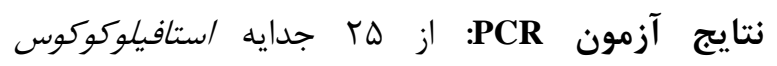

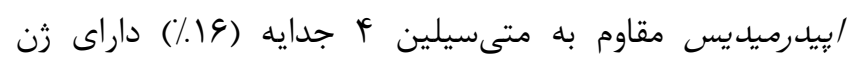
ermA

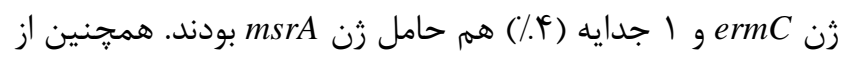

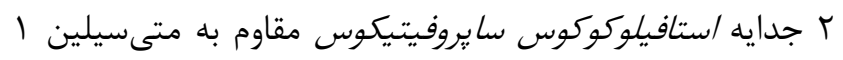

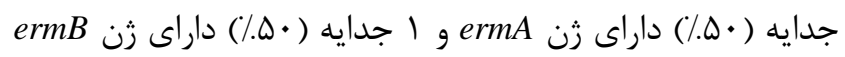

$$
\text { بود (شكل س). }
$$

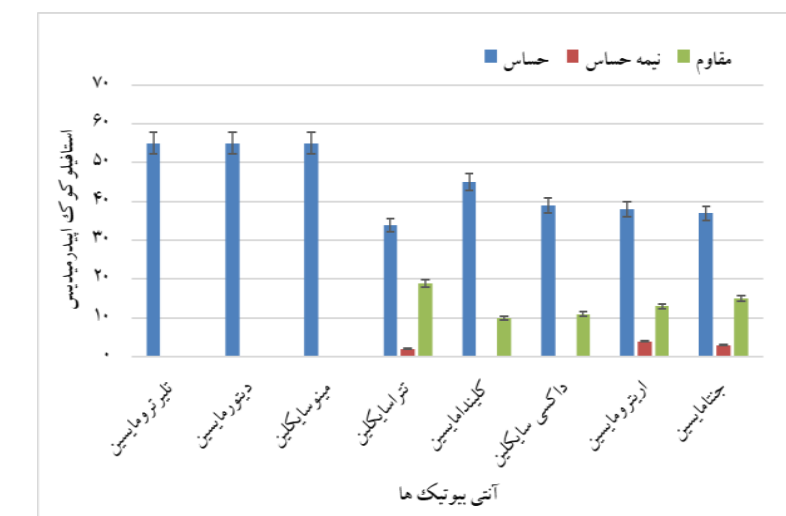

نمودار r. فراوانى الكَوى مقاومت آنتى بيوتيكى هـ جدايهائهاى بالينى

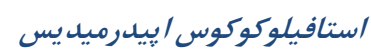

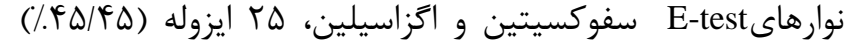

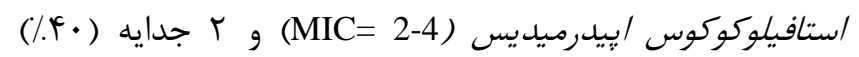

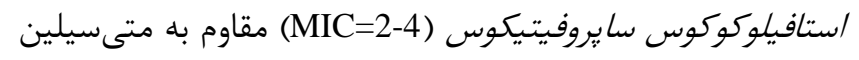
تشخيص داده شدند (شكل ()).

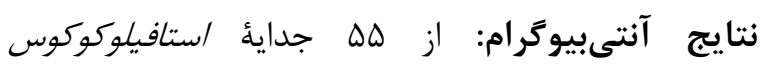

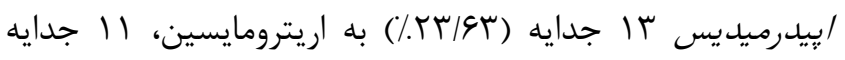

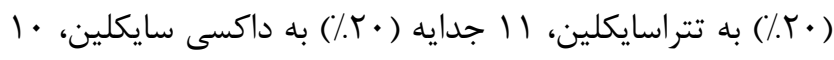

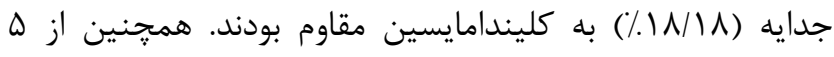

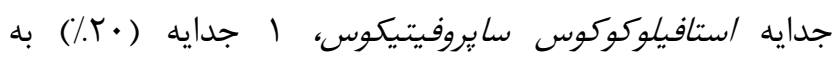

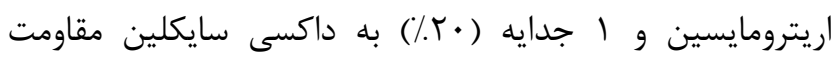
داشتند. نسبت به ساير آنتىبيوتيكها مقاومتى ديده نشد إين (نمودار ( )

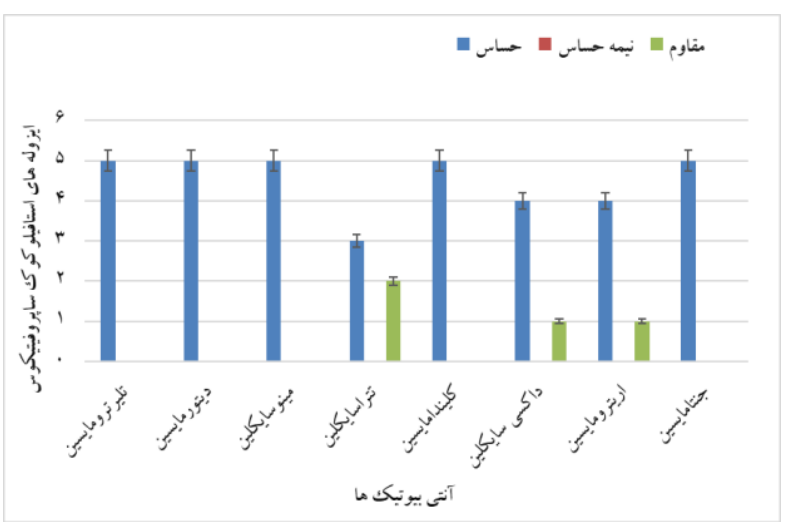

نمودار ا. فراوانى التَوى مقاومت آنتىبيوتيكى ه جدايههاى بالينى

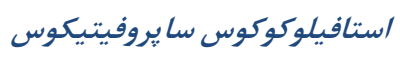
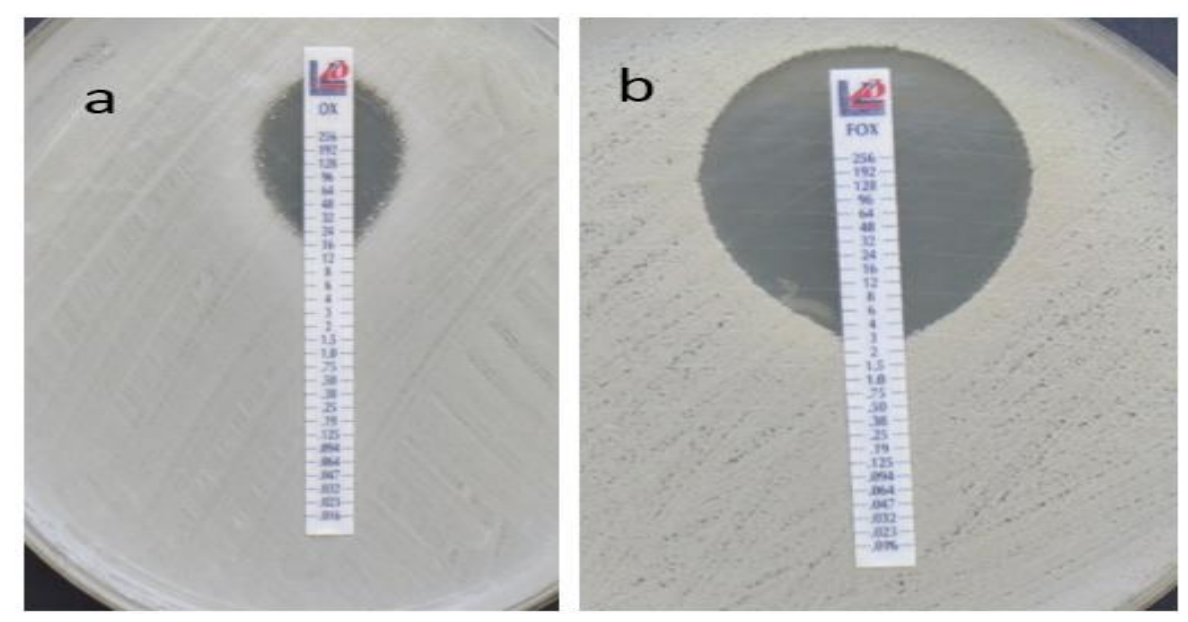

ش-test سكل (. تعيين حداقل غلظت مهارى a) سفوكسيتين و bاكزاسيلين با استفاده از روش 


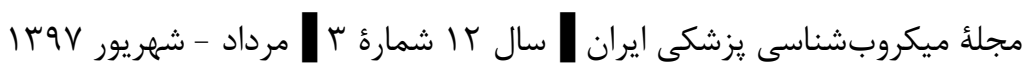

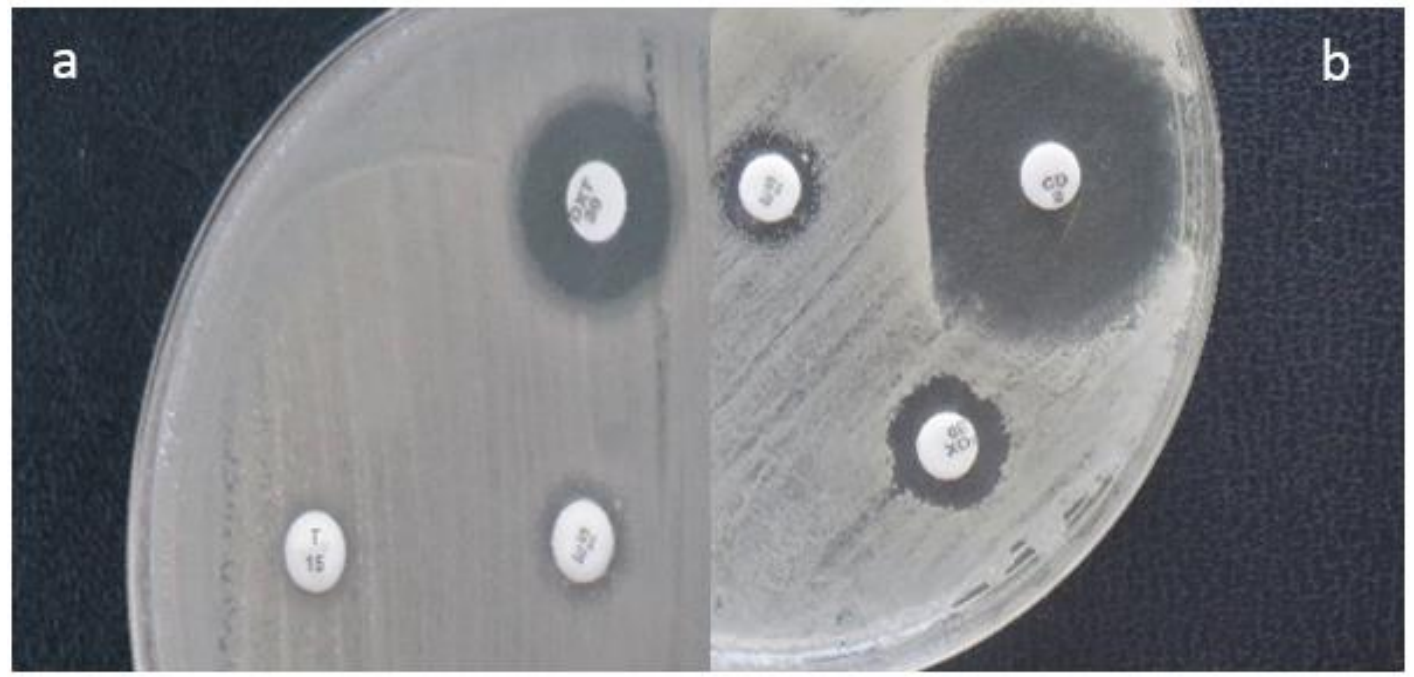

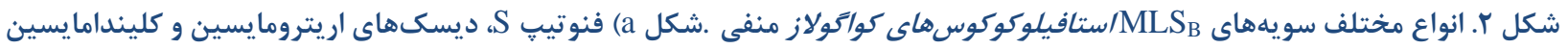

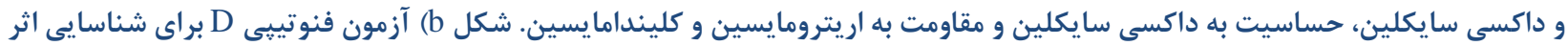
القايى اريترومايسن و كليندامايسين سين

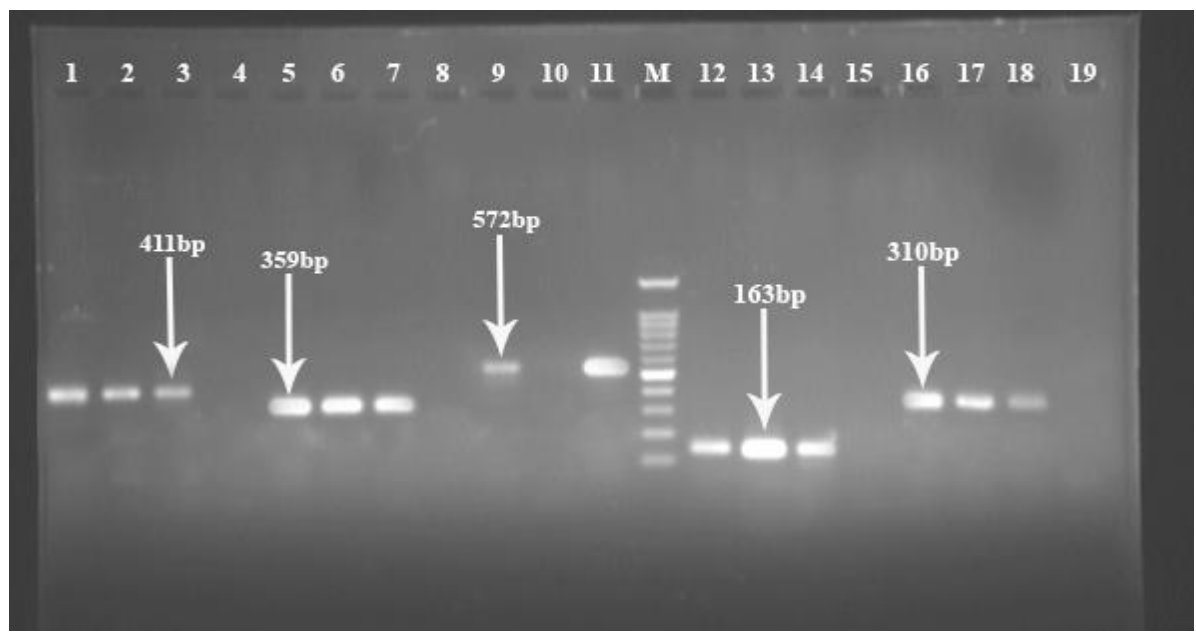

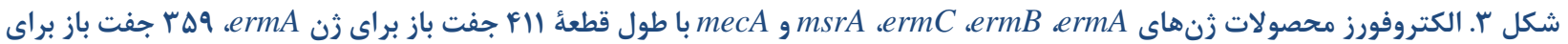

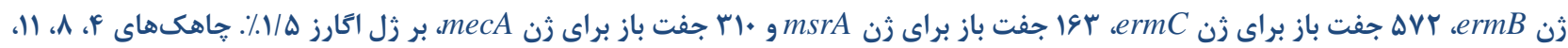

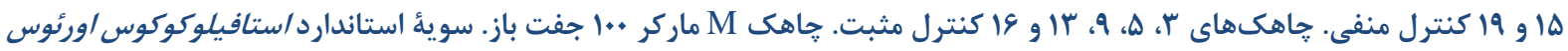

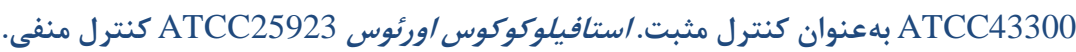

\section{بحث}

استافيلوكوكوس هاى كواكولاز منفى يكى از عوامل اصلى

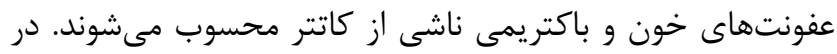

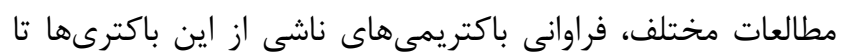

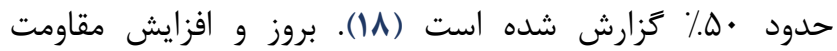
استافيلوكوكوسهاى كواكولاز منفى به متى سيلين و بتالاكتامها،

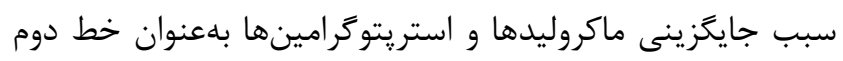
درمانى شده است (19). اين در حالى است كه فشار انتخابى ناشى
تجزيلووتحليل آمارى: با استفاده از آزمون آمارى خ ارتباط معنى دارى بين حضور زن mecA و زنهاى گروه باكترى /ستافيلوكوكوس / إيدرميديس و و /ستافيلوكوكوس سابروفيتيكوس ديده نشد. اين در حالى بود كه ارتباط معنى دارى بين فنوتيٍ القايى كليندامايسين، تتراسايكلين و حضور زن mecA در جدايههاى كوگولاز منفى ديده شد. 


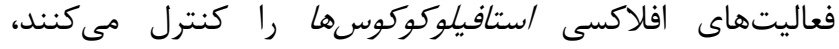

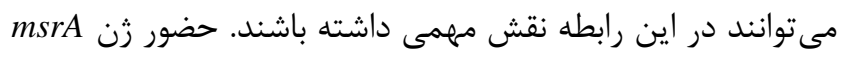

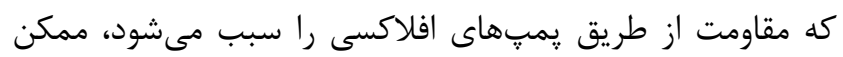

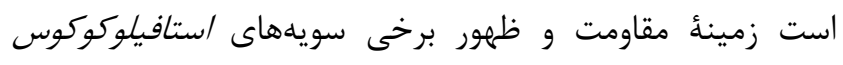

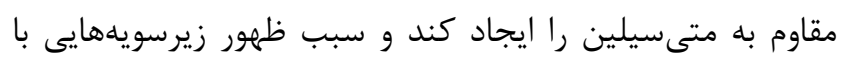

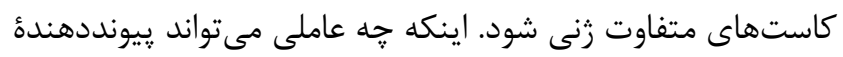

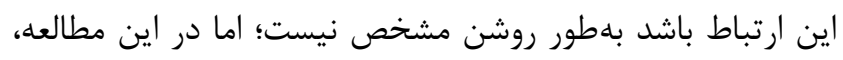

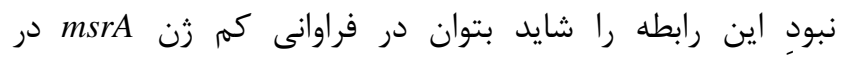

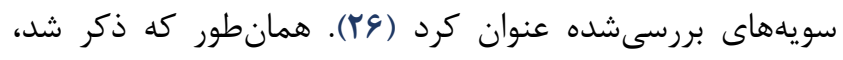

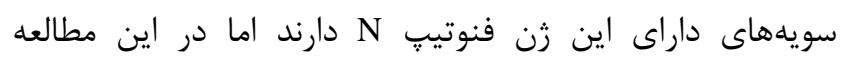

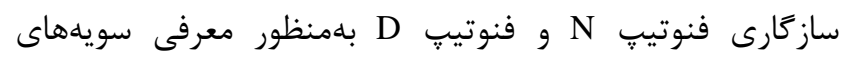

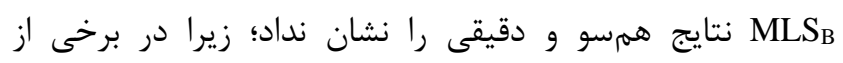

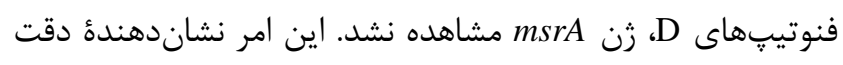

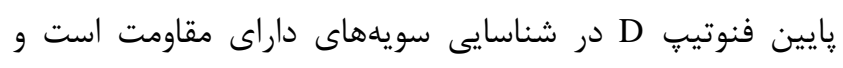

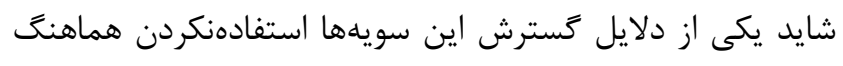
از تمامى تستهاى تشخيصى در تأييد سويههاى MLSB

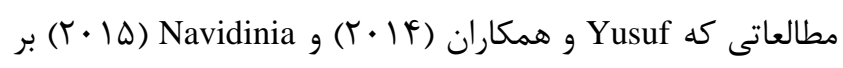
كارآمدى تستهاى فنوتيبى و زنوتيبى بهمنظو

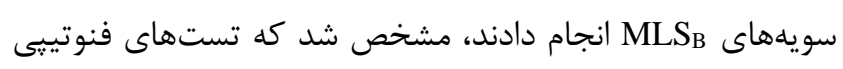

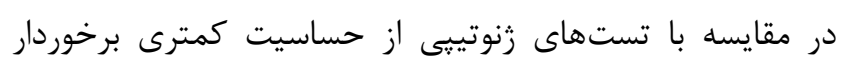

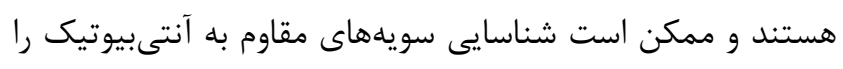

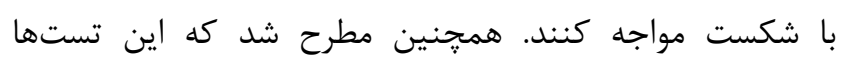

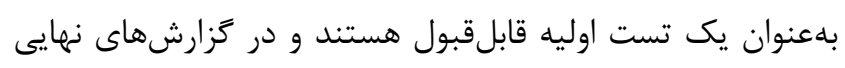

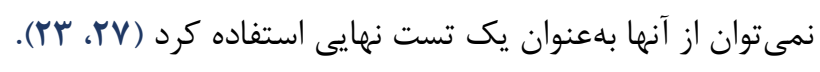

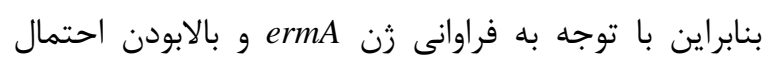

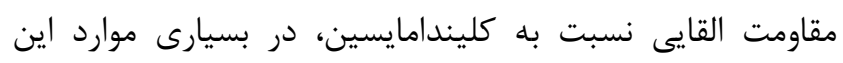

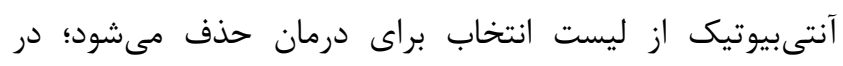

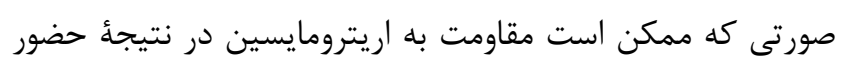

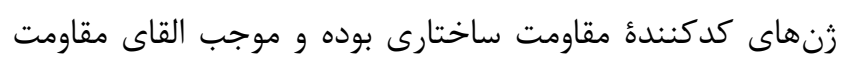

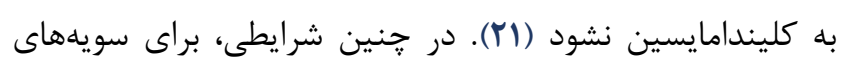

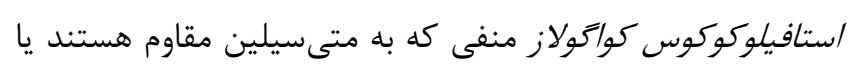

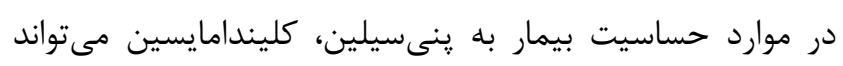

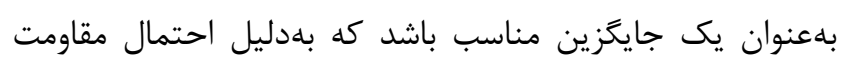

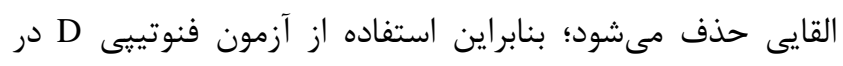

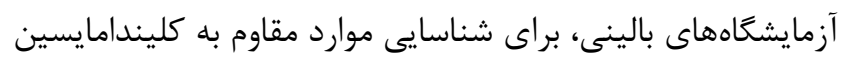
مؤثر است.

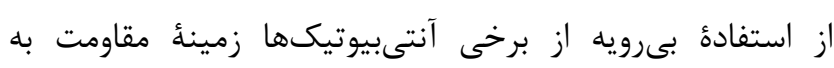

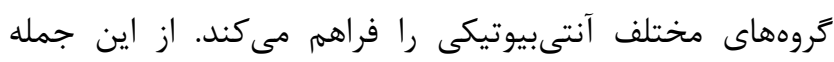

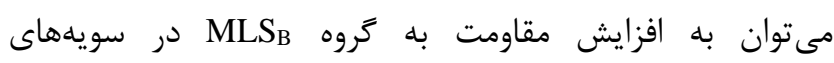

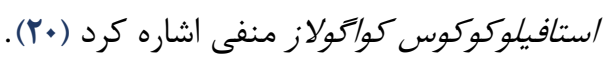

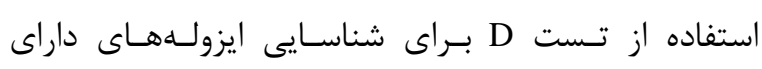

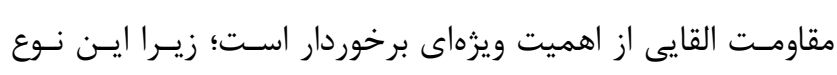

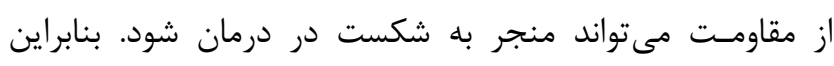

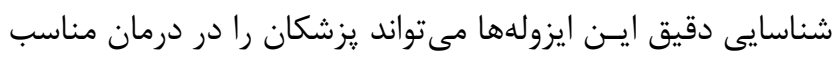

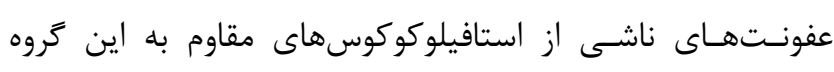

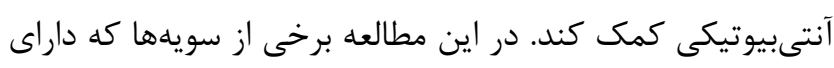

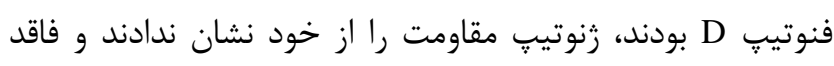

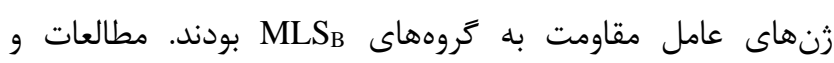

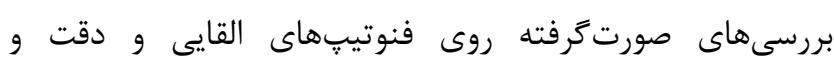

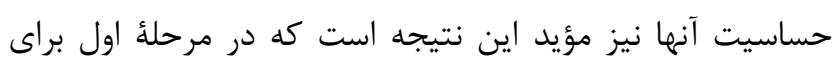

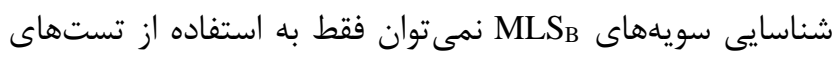

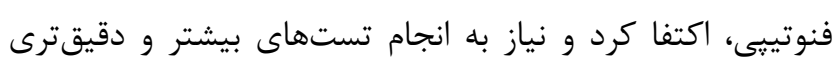

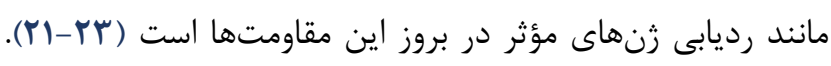

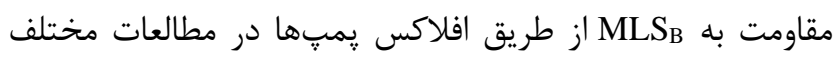

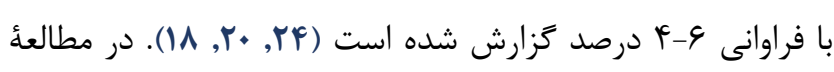

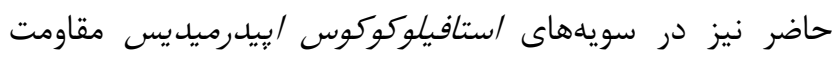

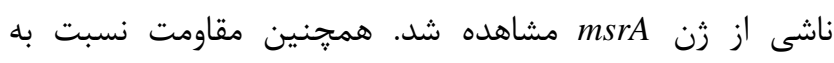

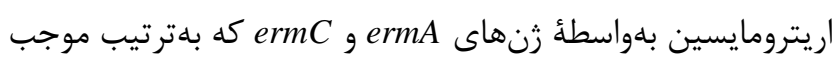

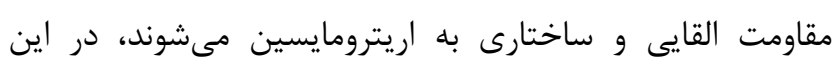

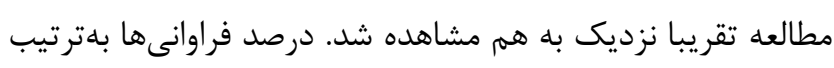

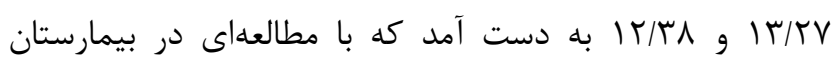

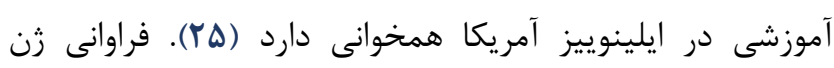
ermC

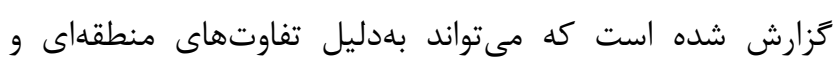

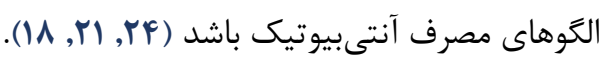

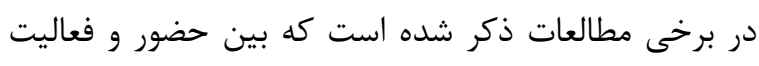
زن عامل مقاومت به متىسيلين و زنهايى كه سبب فعاليتهاي

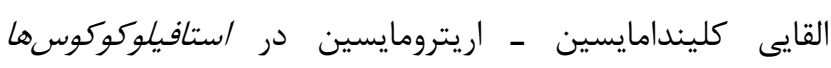

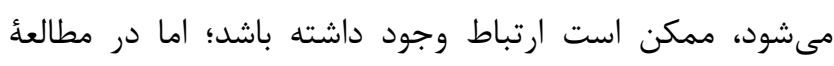

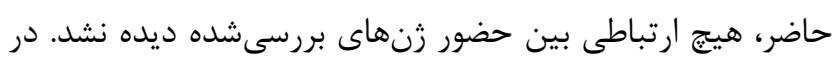

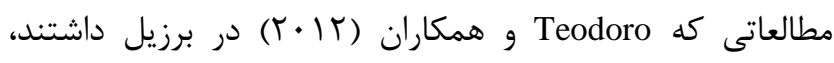
كزارش شد كه برخى سويههاى MLSB

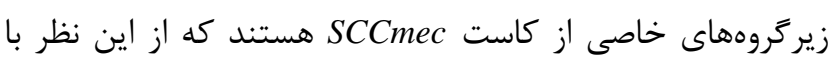

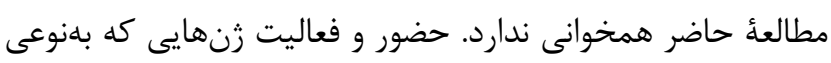


مطالعات با تعداد نمونههاى بيشتر و با استفاده از تكنيكهاى

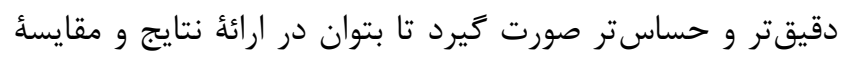

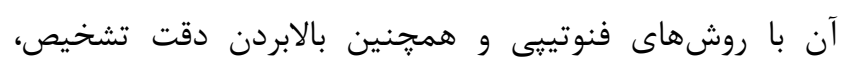
قدمهاى مؤثرترى برداشت.

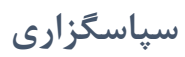

مقاله حاضر با حمايت مالى معاونت يزوهشى دانشعاه

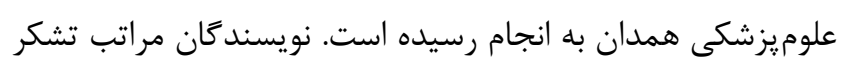
و قدردانى خود را از اين معاونت محترم ابراز مىدارند. تعارض منافع بين نويسند كان تعارض در منافع گزارش نشده است.

\section{References}

1. Sadat Hosseini S, Niakan M, Saderi H, Motallebi M, Taherikalani M, Asadollahi K, et al. Frequency of genes encoding erythromycin ribosomal methylases among Staphylococcus aureus clinical isolates with different D-phenotypes in Tehran, Iran. Iran J Microbiol. 2016;8(3):161-7. PMID:27928482 PMCID:PMC5139918

2. Fiebelkorn KR, Crawford SA, McElmeel ML, Jorgensen JH. Practical disk diffusion method for detection of inducible clindamycin resistance in Staphylococcus aureus and coagulase-negative staphylococci. J Clin Microbiol. 2003;41(10):4740-4. https://doi.org/10.1128/JCM.41.10.4740-4744.2003

PMID:14532213 PMCID:PMC254362

3. Barbier F, Ruppé E, Hernandez D, Lebeaux D, Francois P, Felix B, et al. Methicillin-Resistant Coagulase-Negative Staphylococci in the Community: High Homology of SCCmec IVa between Staphylococcus epidermidis and Major Clones of Methicillin-Resistant Staphylococcus aureus. J Infect Dis. 2010;202(2):270-81. https://doi.org/10.1086/653483 PMID:20550456

4. Vafaee Mehr M, Alikhani M, Tahmasebi H, Arabestani M. Identification and Determination of the Relationship between ccr Alleles and Antibiotic Resistance in Clinical Isolates of Methicillin Resistant Staphylococcus aureus. J Babol Univ Med Sci. 2017;19(12):28-35. http://jbums.org/article-1-6808en.html

5. Bokaeian M, Tahmasebi H, Mohammadzadeh AR, Adabi J, Sepehri Rad N. Comparison of Two PCR Methods in determining the Methicillin-Resistant Gene in Coagulase-Negative Staphylococci. Quarterly of Horizon of Medical Sciences. 2016;22(3):201-7. https://doi.org/10.18869/acadpub.hms.22.3.201

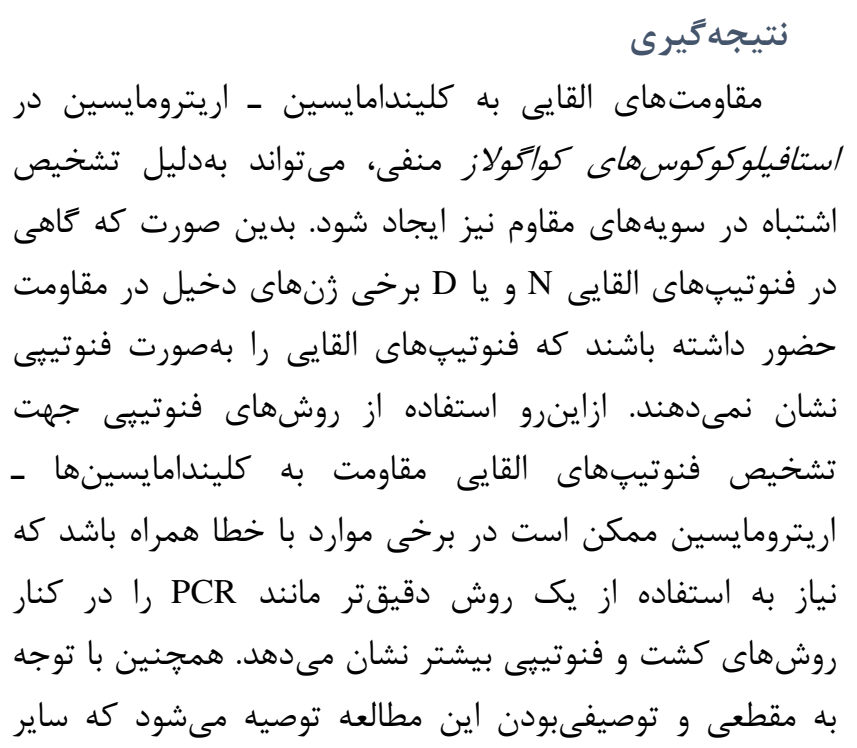

6. Rahman A, Hossain MA, Paul SK, Sultana S, Haque N, Kabir MR, et al. Methicillin-resistant coagulasenegative staphylococci (MRCoNS) by disk diffusion method. Mymensingh Med J. 2013;22(2):229-31. PMID:23715340

7. Goudarzi GR, Azadpour M. Prevalence of Clindamycin Inducible Resistance in Staphylococcus Aureus and Coagulase-Negative Staphylococci Using D-Test: A Short Report. J Rafsanjan Univ Med Sci. 2015;14(1):77-82. http://journal.rums.ac.ir/article-12211-en.html

8. Moosavian M, Shoja S, Rostami S, Torabipour M, Farshadzadeh Z. Inducible clindamycin resistance in clinical isolates of Staphylococcus aureus due to erm genes, Iran. Iran J Microbiol. 2014;6(6):421-7. PMID:25926961 PMCID:PMC4411429

9. Bouchami O, Achour W, Ben Hassen A. Prevalence and mechanisms of macrolide resistance among Staphylococcus epidermidis isolates from neutropenic patients in Tunisia. Clin Microbiol Infect. 2007;13(1):103-6. $\quad$ https://doi.org/10.1111/j.14690691.2006.01567.x PMID: 17184298

10. Uzun B, Gungor S, Pektas B, Aksoy Gokmen A, Yula E, Kocal F, et al. [Macrolide-lincosamide-streptogramin B (MLSB) resistance phenotypes in clinical Staphylococcus isolates and investigation of telithromycin activity]. Mikrobiyol Bul. 2014;48(3):469-76. $\quad$ https://doi.org/10.5578/mb.7748 PMID:25052113

11.Zmantar T, Kouidhi B, Miladi H, Bakhrouf A. Detection of macrolide and disinfectant resistance genes in clinical Staphylococcus aureus and coagulasenegative staphylococci. BMC Res Notes. 2011;4:453. https://doi.org/10.1186/1756-0500-4-453 PMID:22032892 PMCID:PMC3212975 
12. Bokaeian M, Tahmasebi H, Shahraki Zahedani S. Comparison of Susceptibility Testing of E-test Strips with Cefoxitin and Oxacillin Disks in Identification of Methicillin-resistant Staphylococcus saprophyticus Strains. Qom Univ Med Sci J. 2017;11(5):116-26. http://journal.muq.ac.ir/article-1-738-en.html

13. Lindsay JA, Riley TV. Susceptibility to desferrioxamine :a new test for the identification of Staphylococcus epidermidis. J Med Microbiol. 1991;35(1):45-8. https://doi.org/10.1099/00222615-351-45 PMID: 2072377

14. Clinical and Laboratory Standards Institute. Performance standards for antimicrobial susceptibility testing; 24th informational supplement.CLSI M100-S24. Wayne, PA: Clinical and Laboratory Standards Institute; 2014.

15. Kassim A, Omuse G, Premji Z, Revathi G. Comparison of Clinical Laboratory Standards Institute and European Committee on Antimicrobial Susceptibility Testing guidelines for the interpretation of antibiotic susceptibility at a University teaching hospital in Nairobi, Kenya: a cross-sectional study. Ann Clin Microbiol Antimicrob. 2016;15:21 https://doi.org/10.1186/s12941-016-0135-3

PMID:27068515 PMCID:PMC4827198

16. Bokaeian M, Adabi J, Zeyni B, Tahmasebi H. The Presence of aac (6') Ie / aph (2 "), aph (3') - IIIa1, ant (4 ') - Ia1 Genes and Determining Methicillin Resistance in Staphylococcus Epidermidis and Staphylococcus Saprophyticus Strains Isolated from Clinical Specimens. J Arak Uni Med Sci. 2017;19(11):11-25. http://amuj.arakmu.ac.ir/article-1-4534-en.html

17.Lim J-A, Kwon A-R, Kim S-K, Chong Y, Lee K, Choi E-C. Prevalence of resistance to macrolide, lincosamide and streptogramin antibiotics in Gram-positive cocci isolated in a Korean hospital. J Antimicrob Chemother. 2002;49(3):489-95.

https://doi.org/10.1093/jac/49.3.489 PMID:11864949

18. Cetin ES, Gunes H, Kaya S, Aridogan BC, Demirci M. Distribution of Genes Encoding Resistance to Macrolides, Lincosamides and Streptogramins Among Clinical Staphylococcal Isolates in a Turkish University Hospital. J Microbiol Immunol Infect. 2010;43(6):5249. https://doi.org/10.1016/S1684-1182(10)60081-3 PMID:21195981

19. Marosevic D, Kaevska M, Jaglic Z. Resistance to the tetracyclines and macrolide-lincosamide-streptogramin group of antibiotics and its genetic linkage - a review. Ann Agric Environ Med. 2017;24(2):338-44. https://doi.org/10.26444/aaem/74718 PMID:28664720

20.Li L, Feng W, Zhang Z, Xue H, Zhao X. Macrolidelincosamide-streptogramin resistance phenotypes and genotypes of coagulase-positive Staphylococcus aureus and coagulase-negative staphylococcal isolates from bovine mastitis. BMC Vet Res. 2015;11:168. https://doi.org/10.1186/s12917-015-0492-8 PMID:26209340 PMCID:PMC4515024

21. Perez LR, Caierao J, Antunes AL, d'Azevedo PA. Use of the D test method to detect inducible clindamycin resistance in coagulase negative staphylococci (CoNS). Braz J Infect Dis. 2007;11(2):186-8. https://doi.org/10.1590/S1413-86702007000200002 PMID: 17625757

22. O'Sullivan MVN, Cai Y, Kong F, Zeng X, Gilbert GL. Influence of Disk Separation Distance on Accuracy of the Disk Approximation Test for Detection of Inducible Clindamycin Resistance in Staphylococcus spp. J Clin Microbiol. 2006;44(11):4072-6. https://doi.org/10.1128/JCM.01632-06 PMID:17005747 PMCID:PMC1698332

23. Yusuf E, de Bel A, Bouasse J, Pierard D. D-Zone test for detection of inducible clindamycin resistance using SirScan paper disks and Rosco Neo-Sensitabs at 25 and $15 \mathrm{~mm}$ distances. J Med Microbiol. 2014;63(Pt8):10524. PMID:24899599

24. Gatermann SG, Koschinski T, Friedrich S. Distribution and expression of macrolide resistance genes in coagulase-negative staphylococci. Clin Microbiol Infect. 2007;13(8):777-81. https://doi.org/10.1111/j.14690691.2007.01749.x PMID: 17501977

25. Schreckenberger PC, Ilendo E, Ristow KL. Incidence of Constitutive and Inducible Clindamycin Resistance in Staphylococcus aureus and Coagulase-Negative Staphylococci in a Community and a Tertiary Care Hospital. J Clin Microbiol. 2004;42(6):2777-9. https://doi.org/10.1128/JCM.42.6.2777-2779.2004 PMID:15184468 PMCID:PMC427875

26. Teodoro CR, Mattos CS, Cavalcante FS, Pereira EM, dos Santos KR. Characterization of MLS(b) resistance among Staphylococcus aureus and Staphylococcus epidermidis isolates carrying different SCCmec types. Microbiol Immunol. 2012;56(9):647-50. https://doi.org/10.1111/j.1348-0421.2012.00481.x PMID:22672011

27. Navidinia M. Detection of inducible clindamycin resistance (MLSBi) among methicillin-resistant Staphylococcus aureus (MRSA) isolated from health care providers. Journal Of Paramedical Sciences. 2015;6(1):91-6.

http://dx.doi.org/10.22037/jps.v6i1.8380 